\title{
SOPEUTUMISVALMENNUSKURSSEILLE
}

\section{OSALLISTUVIEN LASTEN VANHEMPIEN ARVIOITA HYVINVOINNISTA, TOIMINTAKYVYSTÄ JA KURSSIODOTUKSISTA}

\section{Johdanto}

Sopeutumisvalmennuskurssit ovat osa psykososiaalista kuntoutusta. Kursseja järjestetään eri ikäisille henkilöille, joilla on jokin sairaus tai vamma ja siihen liittyvä toimintakyvyn rajoite, joka vaikeuttaa osallistumista ympäristössä ja yhteiskunnassa. Lasten ja usein nuortenkin kursseilla koko perhe on mukana kuntoutuksessa. Sopeutumisvalmennuksen tavoitteena on antaa tietoa sairaudesta ja sen hoidosta, etsiä keinoja kuntoutujan ja hänen läheistensä omien voimavarojen vahvistumiseen ja tarjota vertaistukea eli kokemusten jakamista toisten kurssilaisten kanssa. Valmennuksella voidaan auttaa lasta ja perhettä hyväksymään sairaus tai vamma ja sopeutumaan sen aiheuttamaan haittaan. (Ahlgren \& Poikkeus 2014, Järvikoski \&t Härkäpää 2014, Mäenpää 2014.)

Sopeutumisvalmennuskursseja toteutetaan terveydenhuollon, Kelan ja Raha-automaattiyhdistyksen järjestäminä. Internaattimuotoista sopeutumisvalmennusta on pidetty erityisesti suomalaisena mallina (esim. Ruutiainen 2003, Nylen ym. 2009). Samanlaisia tavoitteita ja toimintamuotoja sisältyy kansainvälisessä kirjallisuudessa useimmiten avomuotoisesti toteutettuihin psykoedukatiivisiin ja psykososiaalisiin interventioihin (esim. Dagnan 2007, Montoya ym. 2011, Morawska ym. 2015).
Pitkäaikaissairaudella voi olla päivittäisiin rutiineihin ja sosioemotionaaliseen hyvinvointiin liittyviä kielteisiä vaikutuksia lapsen elämään (esim. Morawska ym. 2015). Lapsen pitkäaikaissairaudet (esim. Cousino \&t Hazen 2013) tai kehityksen häiriöt (esim. Theule ym. 2012, Giovagnoli ym. 2015, Miodrag ym. 2015) voivat lisätä vanhempien kokemaa stressiä, joka voi puolestaan heikentää lasten ja vanhempienkin selviytymistä sairauden kanssa (Cousino \&t Hazen 2013). Myös vanhempien ja sisarusten tuen tarpeisiin ja selviytymiskeinoihin tulisi interventioita kehitettäessä kiinnittää huomiota (Burton ym. 2008, Compas ym. 2012, Giallo ym. 2014). Kannustamalla vanhempia huolehtimaan yhdessä lapsen kanssa sairauden tai vamman hoito-ohjeiden toteutuksesta voidaan vähentää vanhempien stressiä ja saada parempia hoitotuloksia (Cousino \&t Hazen 2013). Psykososiaalisilla interventioilla on katsottu voitavan parantaa esimerkiksi diabetesta sairastavien lasten vanhempien selviytymistä ja elämänlaatua (Grey ym. 2011), vaikuttaa myönteisesti pitkäaikaissairaiden lasten vanhempien käyttäytymiseen (Law ym. 2014), tukea ADHD-oireisten lasten myönteistä käyttäytymistä sekä vähentää vanhempien kokemaa stressiä ja vahvistaa luottamusta omaan vanhemmuuteen (Zwi ym. 2011). 
Valtaistumista tai voimaantumista (empowerment) voidaan tarkastella osana sairauteen tai vammaan sopeutumista. Valtaistuminen hahmotetaan usein henkilön lisääntyvinä mahdollisuuksina ja kykyinä määrittää omaa elämänlaatuaan ja vaikuttaa elämäänsä koskeviin asioihin. Tiedon lisääntyminen ja henkilökohtaisten hallintakeinojen vahvistaminen voivat edistää valtaistumista. (Tengland 2008.) Koren ym. (1992) tarkastelevat valtaistumista kolmella eri tasolla: perheen, palvelujärjestelmän ja yhteisön tai politiikan tasolla. Kullakin tasolla valtaistuminen ilmenee sekä asenteina, tietoina että käyttäytymisenä. Erilaiset perheeseen tai palveluihin liittyvät taustatekijät ovat yhteydessä vanhempien valtaistumiseen tai osallisuuteen (Vuorenmaa 2016). Vanhempien valtaistuminen on tutkimusten mukaan yhteydessä esimerkiksi vanhempien parempaan hyvinvointiin (Benson \& Kersh 2011) ja vähäisempään stressiin (Nachshen $C t$ Minnes 2005). Perheen valtaistaminen liittyy läheisesti perhekeskeisen ajattelutavan mukaiseen toimintaan (Rantala 2002). Sopeutumisvalmennuksella on todettu olevan myönteisiä vaikutuksia esimerkiksi astmaa sairastavien perheiden valtaistumiseen (Homan-Helenius 2005).

Perhekeskeisessä hoidossa ja kuntoutuksessa pyritään tarjoamaan perheiden koettuja tarpeita ja odotuksia vastaavia palveluita ja tukea. Perheiden tarpeilla tarkoitetaan sellaisia tiedon ja tuen tarpeita, jotka ovat perheen tai vanhempien itse ilmaisemia ja joiden avulla perhe kokee voivansa saavuttaa itselleen tärkeitä tavoitteita. (Almasri ym. 2011.) Vammaisten lasten vanhemmat raportoivat yleensä enemmän tuen ja palveluiden tarpeita kuin niin sanottujen terveiden lasten vanhemmat (Nachshen \& Minnes 2005, Houtrow ym. 2011). Onkin tärkeää, että niin ammattilaisten kuin pitkäaikaissairaiden lasten vanhempienkin käsityksiä palvelutarpeista ja palveluiden toteutuksesta tutkitaan palveluiden toimeenpanoa kehitettäessä (Morawska ym. 2015).

Sopeutumisvalmennukseen tulevilla lapsilla ja heidän perheillään voi olla monenlaisia tarpeita, kurssin sisältöön kohdistuvia toiveita ja kurssin vaikutuksia koskevia odotuksia.
Aiemman tutkimuksen mukaan vanhempien kurssiodotukset ovat liittyneet erityisesti vertaistukeen ja sairauden hoitoa sekä kuntoutusta ja palveluita koskevaan tietoon (AuttiRämö ym. 2015). Kurssin koetut hyödyt ovat liittyneet erityisesti vertaistukeen tai sairautta koskevan tiedon ja hoitokeinojen vahvistumiseen (Homan-Helenius 2005, Autti-Rämö ym. 2015).

\section{Tutkimuksen tausta ja tarkoitus}

Tämä tutkimus on osa laajempaa Kelan järjestämää sopeutumisvalmennusta koskevaa tutkimushanketta, jossa selvitetään muun muassa sopeutumisvalmennukseen kohdistuvia odotuksia sekä kursseilta saatuja hyötyjä ja koettuja vaikutuksia. Tutkimushankkeen toteuttajana on Lapin yliopisto ja rahoittajana Kela. Tutkimus on hyväksytty Kelan tutkimuseettisessä toimikunnassa. Tutkimus toteutetaan seurantatutkimuksena, joka sisältää alku-, loppu- ja seurantakyselyt. Käsillä oleva artikkeli perustuu sopeutumisvalmennuskursseille osallistuneiden lasten vanhemmille ennen kurssin alkua tehtyyn alkukyselyyn, jossa tiedusteltiin lapsen ja perheen tilannetta sekä kurssiodotuksia ja tuen tarpeita. Tutkimuksen tarkoituksena oli:

1) selvittää eri kurssiryhmiin osallistuneiden lasten psykososiaalista hyvinvointia ja toimintakykyä vanhempien arvioimana,

2) arvioida eri kurssiryhmiin osallistuneiden lasten vanhempien omaa hyvinvointia ja perheiden valtaistumista ja

3) selvittää sopeutumisvalmennukseen kohdistuvia odotuksia ja tuen tarpeita sekä sitä, millaiset lasten ja perheiden hyvinvointiin liittyvät tekijät ovat yhteydessä odotuksiin.

\section{Aineisto ja menetelmät}

Tutkimuksen kohteena olivat diabetesta sairastavien lasten kurssit (D), moni- ja liikuntavammaisten ((MLV; mm. CP-vamma, kehitysvammat) lasten kurssit sekä kurssit lapsille, joilla oli oppimisen tai psyykkisen kehityksen häiriö (OPK; aktiivisuuden ja tarkkaavai- 
suuden häiriö ADHD, Aspergerin oireyhtymä, autismi, kielelliset erityisvaikeudet) ${ }^{1}$. Aineisto kerättiin vuosina 2014-15 kolmen palveluntuottajan kursseilta. Tutkimusta koskeva tiedote, alkukysely- ja suostumuslomakkeet lähetettiin palveluntuottajan toimesta kurssin kutsukirjeen mukana kurssille osallistuneiden lasten vanhemmille. Lomakkeet oli mahdollista täyttää ennen kurssia tai ensimmäisenä kurssipäivänä palveluntuottajan antaman, tutkimusta koskevan infon jälkeen. Alkukyselylomakkeet palautettiin tutkijoille ja suostumuslomakkeet Kelaan.

Kurssit toteutettiin Kelan kuntoutusta ohjaavien kurssikohtaisten standardien mukaisesti; kurssien tavoitteissa, sisällöissä sekä rakenteissa oli eroja kohderyhmittäin (Kela 2013). Diabetesta sairastavien lasten ja nuorten kurssit sekä moni- ja liikuntavammaisten lasten kurssit olivat kestoltaan viisi päivää. Moni- ja liikuntavammaisten nuorten kurssit sekä kaikki kurssit, jotka järjestettiin niille lapsille ja nuorille, joilla oli oppimisen tai psyykkisen kehityksen häiriöitä, toteutettiin kahdessa viiden päivän jaksossa.

Tutkimukseen valituille kursseille osallistui yhteensä 602 lasta. Tämän tutkimuksen aineisto koostuu niistä alle 18-vuotiaiden lasten vanhemmista tai muista huoltajista, jotka antoivat suostumuksensa osallistua tutkimukseen ja vastasivat ennen kurssin alkua tehtyyn lomakekyselyyn ( $\mathrm{n}=357,59$ \%). Alkukyselyyn vastanneiden vanhempien lukumäärät eri kurssimuodoittain olivat 80 (D), 177 (OPK) ja 100 (MLV) ja vastausprosentit vastaavasti $61 \%$ (D), 65 \% (OPK) ja 50 \% (MLV). Kaikkiaan 347 lapsen (97\%) vanhemmat osallistuivat lapsen kurssijaksoon kokonaan, muiden vanhemmat olivat mukana osittain tai eivät lainkaan.

Lomakkeen täyttäjä oli useimmiten äiti (67 \%) tai molemmat vanhemmat yhdessä (27 \%). Isä oli lomakkeen täyttäjä viidessä prosentissa tapauksista. Kurssiryhmien välillä ei ollut tilastollisesti merkitseviä eroja siinä, kuka huoltajista oli täyttänyt lomakkeen. Äitien keski-ikä oli 39.1 vuotta; iässä ei ollut eroja ryhmien välillä. Äideistä 16 \%:lla oli yliopistotasoinen koulutus, 73 \%:lla jokin ammatillinen koulutus ja 11 \%:lla koulutuksena oli peruskoulu tai lukio. D-ryhmän lasten äidit olivat useammin työssä (68 \%) kuin muiden ryhmien äidit (59-60 \%). MLV-ryhmän äideistä yli viidennes oli perhevapaalla tai omaishoitajana, kun muissa ryhmissä vastaavat osuudet olivat $10 \%$ (D) ja $12 \%$ (OPK). Työttöminä oli äideistä $12 \%$.

Alkukyselylomakkeella tiedusteltiin yleisten taustatietojen lisäksi arvioita lapsen terveydestä, toimintakyvystä ja hyvinvoinnista, perheen tai vanhempien hyvinvoinnista, perheen valtaistumisesta sekä kurssiodotuksista seuraavasti:

Lapsen terveys, toimintakyky ja hyvinvointi

- Lapsen terveydentilaa arvioitiin asteikolla 1-5 (1 = hyvä, ..., 5 = huono).

- Toimintakyvyn rajoitteita a) omassa kodissa b) kodin ulkopuolella toimiessa arvioitiin asteikolla 1-4 (1 = ei rajoitteita, ..., 4 = paljon rajoitteita).

- Toimintakyvyn rajoitteen haittaavuutta arvioitiin asteikolla $0-10$, jossa ääripäät oli nimetty ( $0=$ vaikein mahdollinen haitta, $10=$ ei lainkaan haittaava).

- Lapsen hyvinvointia ja elämänlaatua arvioitiin asteikolla 4-10, jossa ääripäät oli nimetty ( 4 = huono tai epätyydyttävä, 10 = erinomainen).

- Lapsen psykososiaalista hyvinvointia, vahvuuksia ja vaikeuksia vanhemmat arvioivat 4-17- vuotiaiden lasten osalta Strengths and Difficulties Questionnaire -kyselyllä (SDQ; ks. Goodman 1997, 2001). Se koostuu 25 väittämästä, jotka jakautuvat viiteen osa-asteikkoon: tunne-elämän oireet, käytösoireet, yliaktiivisuuden/ tarkkaavaisuuden oireet, kaverisuhteiden ongelmat ja lapsen vahvuudet. Neljän ensimmäisen osa-asteikon summana muodostettu kokonaispistemäärä (vaihteluväli 0-40) suositellaan luokiteltavaksi seuraa-

\footnotetext{
${ }^{1}$ Tekstissä käytetään lyhenteitä $\mathrm{D}=$ diabetes, OPK = oppimisen tai psyykkisen kehityksen häiriöt, MLV = moni- ja liikuntavammat.
} 
vasti: ei merkittävää oireilua (0-13), jonkin verran oireilua (14-16), kliinisesti merkittävää oireilua (17-40) (SDQ 2016). Mittarin suomalaista versiota on käytetty useissa tutkimuksissa (esim. Koskelainen ym. 2000, 2001, Linnakangas ym. 2010, Borg ym. 2012).

Vanhempien tai perheen hyvinvointi ja valtaistuminen

- Vanhempien hyvinvointia, voimavaroja ja tyytyväisyyttä elämään sekä sisarusten hyvinvointia arvioitiin kutakin asteikolla 4-10 (4 = huono tai epätyydyttävä, 10 = erinomainen).

- Perheiden valtaistumista arvioitiin 10-osioisella kysymyssarjalla, jonka pohjana käytettiin Korenin ym:iden (1992) perheen valtaistumisen mittaria (Family Empowerment Scale). Kutakin osiota arvioitiin asteikolla 1-5 (1 = ei pidä lainkaan paikkaansa, 5 = pitää täysin paikkansa). Faktorianalyysin perusteella (pääkomponenttianalyysi, varimax-rotaatio) muodostettiin kolme summamuuttujaa, joista ensimmäinen koski sairauden tiedollista hallintaa (4 osiota, esim. "Tunnen, että minulla on riittävästi tietoa lapseni sairauden hoidosta ja kuntoutuksesta”, Cronbachin alfa $\alpha=0.76$ ), toinen itsearvostusta ja valmiutta sairaudesta puhumiseen (4 osiota, esim. "Minun ja lapseni mielipiteen tulee olla yhtä tärkeä kuin asiantuntijan päätettäessä millaisia palveluja lapsi tarvitsee”, $\alpha=0.61$ ) ja kolmas perheen selviytymisen tunnetta ja ongelmien hallintaa (2 osiota, esim. "Perheemme pystyy keskittymään hyviin asioihin elämässä, ei vain ongelmiin", Spearman-Brown (SB) = 0.67). Summamuuttujat jaettiin osioiden määrällä, joten niiden vaihteluväli on 1-5.

\section{Kurssiodotukset}

- Kursseihin kohdistuvia odotuksia kartoitettiin 24 osion kysymyssarjalla, jonka laadinnassa käytettiin hyväksi aiempia tutkimuksia (Linnakangas ym. 2010, AuttiRämö ym. 2015). Kunkin kurssiodotuksen voimakkuutta arvioitiin asteikolla 1-4 (1
= en yhtään/ei tarvetta, 4 = erittäin paljon). Faktorianalyysin (pääkomponenttianalyysi, varimax-rotaatio) tulosten perusteella muodostettiin kuusi odotusfaktoria laskemalla yhteen osioiden pistemäärät ja jakamalla summa osioiden määrällä; kunkin faktorin vaihteluväli oli siten 1-4. Odotusfaktorit (F) koskivat F1) tietoa tukimuodoista ja palveluista (7 osiota, $\propto=$ 0.86); F2) tukea vanhemmille ja perheelle (4 osiota, $\alpha=0.78$ ); F3) lapsen kasvun ja kehityksen tukemista (4 osiota, $\alpha=0.76$ ); F4) vertaistukea ja yhdessäoloa (3 osiota, $\alpha=0.66)$; F5) tietoa ja ohjausta sairauteen ja hoitoon (3 osiota, $\alpha=0.64$ ); sekä F6) opastusta kouluasioihin ja tulevaisuuteen ( 2 osiota, SB $=0.58$ ). Yksi osio (sisarusten tarpeiden huomioonottaminen) jätettiin odotusfaktoreiden ulkopuolelle, koska sen kommunaliteetti oli pieni.

\section{Tilastollinen analyysi}

Analyyseissa käytettiin frekvenssijakautumia, ristiintaulukointeja ja Khiin neliö -testiä, Spearmanin järjestyskorrelaatiokerrointa, riippumattomien ryhmien t-testiä, yksisuuntaista varianssianalyysiä, kovarianssianalyysiä ja logistista regressioanalyysiä. Analyyseja varten joitakin muuttujaluokkia yhdistettiin.

Logistisessa regressioanalyysissä selitettävinä muuttujina käytettiin kurssiodotusten viittä ensimmäistä odotusfaktoria. Analyysissa ennustettiin odotusten suurempaa määrää. Faktorit dikotomisoitiin analyyseja varten seuraavasti: F1: raja-arvo $\geq 2.4(55 \%)$, F2: raja-arvo $\geq 2.6$ (46 \%), F3: raja-arvo $\geq 2.6$ (50 \%), F4: raja-arvo $\geq 3.4$ (50 \%), F5: rajaarvo $\geq 2.8(48 \%)$.

Analyysissä selvitettiin ensin kunkin yksittäisen selittävän muuttujan yhteys selitettävään muuttujaan. Sen jälkeen kokonaismalliin valittiin ne muuttujat, joilla oli yksittäisissä analyyseissä tilastollisesti merkitsevä yhteys selitettävään muuttujaan. Kokonaismallissa kovariantteina käytettiin lapsen ikää ja kurssiryhmää. Analyysit tehtiin IBM SPSS Statistics -ohjelman versiolla 21. 


\section{Tulokset}

\section{Osallistujat}

Kursseille osallistuneista lapsista ( $\mathrm{n}=357$ ) lähes $70 \%$ oli poikia. OPK-kursseilla poikien osuus oli suurempi (80\%) kuin kahdessa muussa kurssiryhmässä. Valtaosa kurssilaisista oli alakoululaisia tai alle kouluikäisiä. MLVkurssien osallistujista yli puolet oli alle kouluikäisiä, muilla kursseilla osuus oli pienempi. Lapsista $72 \%$ asui molempien vanhempien kanssa samassa taloudessa ja 88 \%:lla oli sisaruksia perheessä. Kelan vammaistukea sai 93 \% lapsista; MLV-ryhmän lapsista yli $90 \%$ sai korotettua tai ylintä vammaistukea. Valtaosa OPK- ja MLV-kursseille osallistuneista kouluikäisistä lapsista sai jotain erityistä tukea koulussa, esimerkiksi erityisopetusta, avustajan tukea, pienryhmäopetusta ja oppiaineiden helpottamista. Kolmannes lapsista oli osallistunut sopeutumisvalmennuskursseille myös aiemmin. (Taulukko 1.)
Lasten terveydentila, hyvinvointi ja toimintakyky

Vanhemmista vajaa $80 \%$ arvioi lapsen terveydentilan hyväksi tai melko hyväksi, ja ainoastaan muutama prosentti arvioi sen huonoksi. Kurssiryhmien välillä ei ollut tilastollisesti merkitseviä eroja terveydentilan arvioissa. (Taulukko 2.) Tyttöjen terveydentila arvioitiin jonkin verran paremmaksi kuin poikien $(\mathrm{p}<.05)$.

Toimintakyvyn rajoitteita lapsella arvioitiin olevan omassa kodissa toimiessa $80 \%$ :lla ja kodin ulkopuolella toimiessa 91 \%:lla. Rajoitteiden aiheuttama haitta arvioitiin vaikeaksi (arvot 0-3 asteikolla 0-10) 27 \%:lla ja lieväksi (arvot 8-10) $18 \%$ :lla. Toimintakyvyn rajoitteet arvioitiin suurimmiksi MLV-ryhmässä ja pienimmiksi D-ryhmässä. Lasten hyvinvointi ja elämänlaatu arvioitiin yleensä hyväksi tai tyydyttäväksi. SDQ-kyselyn mukaan OPK-ryhmässä oli eniten kliinisesti merkittävää oireilua (58 \%:lla). (Taulukko 2.) Kaikki kurssiryhmien

Taulukko 1. Perustietoja kurssiryhmittäin', \%.

\begin{tabular}{|c|c|c|c|c|c|}
\hline & \multicolumn{3}{|c|}{ Kurssiryhmä } & \multirow[b]{2}{*}{$\begin{array}{c}\text { Kaikki } \\
(n=345-356)\end{array}$} & \multirow[b]{2}{*}{$\mathrm{p}^{2}$} \\
\hline & $\begin{array}{c}D \\
(n=74-80)\end{array}$ & $\begin{array}{c}\text { OPK } \\
(n=172-177)\end{array}$ & $\begin{array}{c}\text { MLV } \\
(n=99-100)\end{array}$ & & \\
\hline Lapsen sukupuoli: poikia & 58.2 & 80.2 & 58.0 & 69.1 & $<.001$ \\
\hline Lapsen ikä vuosina & & & & & $<.001$ \\
\hline $1-6$ & 19.0 & 24.9 & 54.0 & 31.7 & \\
\hline $7-11$ & 54.4 & 46.9 & 36.0 & 45.5 & \\
\hline \multirow[t]{2}{*}{$12-17$} & 26.6 & 28.2 & 10.0 & 22.8 & \\
\hline & 100 & 100 & 100 & 100 & \\
\hline Lapsen pääasiallinen asuminen & & & & & .087 \\
\hline molempien vanhemp. luona samassa taloudessa & 75.9 & 66.7 & 78.0 & 71.9 & \\
\hline \multirow[t]{2}{*}{ muu vaihtoehto } & 24.1 & 33.3 & 22.0 & 28.1 & \\
\hline & 100 & 100 & 100 & 100 & \\
\hline Sisaruksia: kyllä & 92.4 & 84.7 & 90.9 & 88.1 & .126 \\
\hline \multicolumn{6}{|l|}{ Lapselle myönnetty Kelan vammaistuki } \\
\hline ei & 5.4 & 11.0 & - & 6.7 & $<.001$ \\
\hline perustuki & 16.2 & 32.0 & 8.1 & 21.7 & \\
\hline korotettu tuki & 68.9 & 53.5 & 80.8 & 64.6 & \\
\hline \multirow[t]{2}{*}{ ylin tuki } & 9.5 & 3.5 & 11.1 & 7.0 & \\
\hline & 100 & 100 & 100 & 100 & \\
\hline $\begin{array}{l}\text { Koulussa olevan lapsen saama erityinen tuki } \\
\text { ( } n=247) \text { : kyllä }\end{array}$ & 31.7 & 85.7 & 86.3 & 72.1 & $<.001$ \\
\hline Aiempi sopeutumisvalmennus: kyllä & 36.3 & 28.2 & 48.5 & 35.7 & .003 \\
\hline
\end{tabular}

${ }^{1} \mathrm{D}=$ diabetes, $\mathrm{OPK}=$ oppimisen tai psyykkisen kehityksen häiriöt, $\mathrm{MLV}=$ moni- ja liikuntavammaisuus ${ }^{2} x^{2}$-testi 
väliset erot säilyivät myös ikävakioinnin jälkeen. Myös kurssiryhmien sisällä terveydentilan, toimintakyvyn ja hyvinvoinnin arviot vaihtelivat runsaasti; useilla muuttujilla arviot jakautuivat asteikon kaikkiin osiin.

Alle 7-vuotiaiden lasten ryhmässä, jossa moni- ja liikuntavammaisten lasten osuus oli suurin, oli vanhempien arvioiden mukaan enemmän toimintakyvyn rajoitteita kuin vanhemmilla lapsilla. Nuorempien lasten hyvin- vointi arvioitiin kuitenkin paremmaksi kuin vanhempien ikäryhmien. Tyttöjen hyvinvointi oli SDQ-kyselyn mukaan hieman poikia parempi $(\mathrm{p}<.05)$.

\section{Vanhempien ja perheen koettu hyvinvointi ja valtaistuminen}

Vanhemmat arvioivat oman hyvinvointinsa, voimavarat ja tyytyväisyyden elämään keski-

Taulukko 2. Vanhempien arviot lapsen terveydestä, toimintakyvystä ja hyvinvoinnista kurssiryhmittäin', \%.

\begin{tabular}{|c|c|c|c|c|c|}
\hline & \multicolumn{3}{|c|}{ Kurssiryhmä } & \multirow[b]{2}{*}{$\begin{array}{c}\text { Kaikki } \\
(n=345-356)\end{array}$} & \multirow[b]{2}{*}{$\mathrm{p}^{2}$} \\
\hline & $\begin{array}{c}D \\
(n=77-80)\end{array}$ & $\begin{array}{c}\text { OPK } \\
(n=174-176)\end{array}$ & $\begin{array}{c}\text { MLV } \\
(n=96-98)\end{array}$ & & \\
\hline Lapsen terveydentila & & & & & .829 \\
\hline hyvä/melko hyvä & 83.8 & 77.8 & 78.6 & 79.4 & \\
\hline keskitasoinen & 13.8 & 19.3 & 19.4 & 18.1 & \\
\hline \multirow[t]{2}{*}{ melko huono/huono } & 2.5 & 2.8 & 2.0 & 2.5 & \\
\hline & 100 & 100 & 100 & 100 & \\
\hline $\begin{array}{l}\text { Toimintakyvyn rajoitteet omassa kodissa } \\
\text { toimiessa }\end{array}$ & & & & & $<.001$ \\
\hline ei & 40.5 & 17.7 & 7.3 & 20.0 & \\
\hline jonkin verran & 51.9 & 54.3 & 46.9 & 51.7 & \\
\hline \multirow[t]{2}{*}{ melko paljon/paljon } & 7.6 & 28.0 & 45.8 & 28.3 & \\
\hline & 100 & 100 & 100 & 100 & \\
\hline $\begin{array}{l}\text { Toimintakyvyn rajoitteet kodin ulkopuolella } \\
\text { toimiessa }\end{array}$ & & & & & $<.001$ \\
\hline ei & 22.8 & 7.5 & 2.1 & 9.5 & \\
\hline jonkin verran & 55.7 & 46.0 & 30.2 & 43.8 & \\
\hline \multirow[t]{2}{*}{ melko paljon /paljon } & 21.5 & 46.6 & 67.7 & 46.7 & \\
\hline & 100 & 100 & 100 & 100 & \\
\hline Toimintakyvyn rajoitteen haittaavuus & & & & & $<.001$ \\
\hline 0-3 (vaikea haitta) & 10.4 & 25.6 & 42.7 & 26.9 & \\
\hline $4-7$ & 49.4 & 63.1 & 46.9 & 55.6 & \\
\hline \multirow[t]{2}{*}{ 8-10 (ei haittaava) } & 40.3 & 11.4 & 10.4 & 17.5 & \\
\hline & 100 & 100 & 100 & 100 & \\
\hline Lapsen hyvinvointi ja elämänlaatu & & & & & $<.001$ \\
\hline 4-6 (huono, epätyydyttävä) & 1.3 & 8.0 & 9.1 & 6.8 & \\
\hline $7-8$ & 38.0 & 68.0 & 46.0 & 55.2 & \\
\hline \multirow[t]{2}{*}{ 9-10 (erinomainen) } & 60.8 & 24.0 & 45.0 & 38.0 & \\
\hline & 100 & 100 & 100 & 100 & \\
\hline SDQ-pistemäärä (4-17-vuotiaat, n=305) & & & & & $<.001$ \\
\hline ei merkittävää oireilua (0-13 p) & 78.6 & 19.5 & 39.5 & 38.0 & \\
\hline jonkin verran oireilua (14-16 p) & 7.1 & 22.6 & 18.4 & 18.0 & \\
\hline \multirow[t]{2}{*}{ kliinisesti merkittävää oireilua (17-40 p) } & 14.3 & 57.9 & 42.1 & 43.9 & \\
\hline & 100 & 100 & 100 & 100 & \\
\hline
\end{tabular}

${ }^{1} \mathrm{D}=$ diabetes, $\mathrm{OPK}=$ oppimisen tai psyykkisen kehityksen häiriöt, $\mathrm{MLV}=$ moni- ja liikuntavammaisuus ${ }^{2} \mathrm{x}^{2}$-testi 
määrin hyväksi tai tyydyttäväksi. Lapsen sisarusten hyvinvointi arvioitiin jonkin verran vanhempien hyvinvointia paremmaksi. Vanhempien arviot omasta ja lapsen sisarusten hyvinvoinnista olivat D-ryhmässä myönteisimmät ja erosivat tilastollisesti merkitsevästi OPK-ryhmän vanhempien arvioista. Perheiden valtaistumismittarin osa-asteikoilla OPK-ryhmän keskiarvot olivat matalimmat. (Taulukko 3.) Arviot vaihtelivat myös kaikkien kurssiryhmien sisällä.

Vanhempien arvio omasta hyvinvoinnistaan korreloi lapsen hyvinvointia $(\mathrm{r}=0.51, \mathrm{p}$ $<.01)$ ja hänen sisarustensa hyvinvointia $(\mathrm{r}=$ $0.53, \mathrm{p}<.01)$ koskevien arvioiden kanssa. Lapsen SDQ-pistemäärä korreloi negatiivisesti sisarusten hyvinvointiin $(\mathrm{r}=-0.41, \mathrm{p}<.01)$ sekä perheiden valtaistumismittarin selviytymistä ja ongelmien hallintaa koskevan summamuuttujan kanssa $(\mathrm{r}=-0.42, \mathrm{p}<.01)$.

\section{Kurssiodotukset}

Kuvio 1 esittää vanhempien odotuksia sopeutumisvalmennuskursseilta saatavasta tuesta eri kurssiryhmissä odotusfaktoreiden mukaan ryhmiteltynä. Eniten odotuksia kaikissa ryhmissä kohdistui vertaistuen saamiseen sekä virkistymiseen ja yhdessäoloon, joita 81-99 $\%$ lasten vanhemmista odotti saavansa melko tai erittäin paljon. Kaikissa ryhmissä 71-75 \%:a vanhemmista odotti saavansa myös paljon tietoa lapsen sairauden hoidosta ja kuntoutuksesta. OPK- ja MLV-ryhmän vanhemmat toivoivat usein saavansa kurssilta tukea omaan jaksamiseen vanhempana. Heillä oli myös enemmän tukimuotoihin, perheen tukemiseen, kouluasioihin ja tulevaisuuden suunnitteluun liittyviä odotuksia kuin D-ryhmän vanhemmilla. OPK-ryhmän vanhemmat odottivat usein tukea myös lapsen tunnetilojen käsittelyyn. D-ryhmän vanhemmat pitivät tärkeänä erityisesti lapselle saatavaa vertaistukea. Myös tukea ja ohjausta lapsen sairauden hyväksymisessä odotettiin D-ryhmässä hieman muita ryhmiä useammin. (Kuvio 1.)

Tukimuotoja ja palveluita (F1) sekä sairauden hoitoa ja kuntoutusta (F5) koskevien odotusten todennäköisyyttä vähensi lapsen korkeampi ikä, lapsen toimintakyvyn vähäisemmät rajoitteet sekä vanhempien parempi hyvinvointi ja valtaistuminen. Tukimuotoihin ja palveluihin liittyvien runsaiden odotusten todennäköisyyttä lisäsivät lapsen kuuluminen OPK- tai MLV-ryhmään. (Taulukko 4.)

Vanhempien ja perheen saamaan tukeen

Taulukko 3. Vanhempien ja perheen hyvinvointia koskevat arviot kurssiryhmittäin'.

Keskiarvot (keskihajonnat) ja keskiarvojen erojen tilastollinen merkitsevyys (p).

\begin{tabular}{|l|c|c|c|c|c|c|}
\hline \multirow{2}{*}{ Psykososiaaliset tekijät } & \multicolumn{3}{|c|}{ Kurssiryhmä } & \multirow{2}{*}{ Kaikki } & F & $p^{2}$ \\
\cline { 2 - 6 } & $\begin{array}{c}\text { OPK } \\
(n=78-79)\end{array}$ & $\begin{array}{c}\text { MLV } \\
(n=174-176)\end{array}$ & & & \\
\hline Hyvinvointi ja voimavarat & & & & & & \\
\hline vanhempien hyvinvointi & $7.81(1.05)^{\mathrm{a}}$ & $7.27(1,26)^{\mathrm{a}}$ & $7.55(1.14)$ & $7.47(1.20)$ & 5.85 & .003 \\
\hline vanhempien voimavarat & $7.54(1.09)^{\mathrm{a}}$ & $7.09(1.23)^{\mathrm{a}}$ & $7.32(1.06)$ & $7.25(1.17)$ & 4.42 & .013 \\
\hline tyytyväisyys elämään & $8.19(0.99)^{\mathrm{a}}$ & $7.56(1.12)^{\mathrm{a}}$ & $7.85(1.15)$ & $7.78(1.13)$ & 9.17 & $<.001$ \\
\hline sisarusten hyvinvointi $(\mathrm{n}=307)$ & $8.69(0.74)^{\mathrm{a}}$ & $7.91(1.26)^{\mathrm{ab}}$ & $8.31(0.96)^{\mathrm{b}}$ & $8.21(1.12)$ & $16.30^{3}$ & $<.001$ \\
\hline Perheiden valtaistuminen & & & & & & \\
\hline sairauden tiedollinen hallinta & $3.84(0.57)^{\mathrm{a}}$ & $3.42(0.75)^{\mathrm{a}}$ & $3.61(0.61)$ & $3.57(0.69)$ & $11.73^{3}$ & $<.001$ \\
\hline $\begin{array}{l}\text { itsearvostus ja valmius } \\
\text { sairaudesta puhumiseen }\end{array}$ & $4.35(0.48)^{\mathrm{a}}$ & $4.02(0.61)^{\mathrm{a}}$ & $4.18(0.56)$ & $4.14(0.58)$ & 9.07 & $<.001$ \\
\hline $\begin{array}{l}\text { selviytymisen tunne ja } \\
\text { ongelmien hallinta }\end{array}$ & $4.30(0.60)^{\mathrm{a}}$ & $3.88(0.73)^{\mathrm{ab}}$ & $4.16(0.67)^{\mathrm{b}}$ & $4.05(0.71)$ & 12.02 & $<.001$ \\
\hline
\end{tabular}

${ }^{1} \mathrm{D}=$ diabetes, $\mathrm{OPK}=$ oppimisen tai psyykkisen kehityksen häiriöt, $\mathrm{MLV}=$ moni- ja liikuntavammaisuus

${ }^{2}$ Ryhmäerojen merkitsevyyden testauksessa käytetty yksisuuntaista varianssianalyysiä

${ }^{3}$ F-testin sijaan käytetty Brown-Forsythe-testiä, koska ryhmien varianssit erosivat toisistaan tilastollisesti merkitsevästi

${ }^{a} \mathrm{D}$ - ja OPK-ryhmien ero vähintään $\mathrm{p}<.05$

b OPK-ja MLV-ryhmien ero vähintään $\mathrm{p}<.05$ 
(F2) liittyviä odotuksia lisäsi lapsen kuuluminen MLV-ryhmään, lapsen toimintakyvyn suuremmat rajoitukset, vanhempien heikompi hyvinvointi sekä perheen heikompi selviytymisen tunne ja ongelmien hallinta. Lapsen kasvun ja kehityksen tukemiseen (F3) liittyviä odotuksia lisäsivät myös lapsen heikom- pi psykososiaalinen hyvinvointi (SDQ), lapsen kuuluminen OPK- tai MLV-ryhmään sekä heikompi valtaistuminen kaikilla valtaistumisen osa-alueilla. Vertaistukeen liittyvien odotusten (F4) todennäköisyyttä lisäsivät perheen vahvempi valtaistuminen, erityisesti itsearvostuksen ja keskusteluvalmiuden sekä

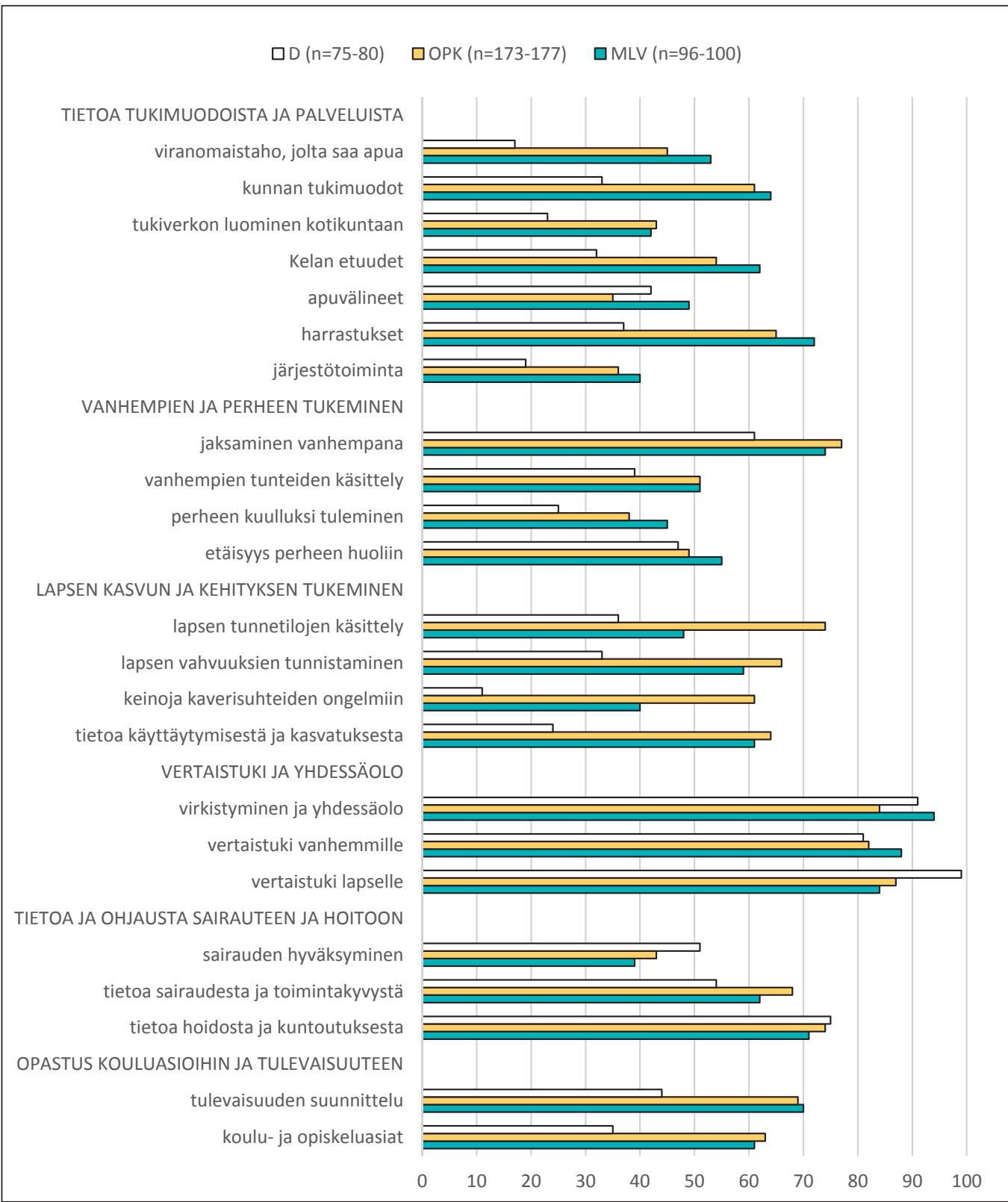

Kuvio 1. Odotukset sopeutumisvalmennuskursseilta saatavasta tuesta kurssiryhmittäin: $\mathrm{D}=$ diabetes, OPK $=$ oppimisen tai psyykkisen kehityksen häiriöt, MLV = moni- ja liikuntavammaisuus, ("melko paljon" tai "erittäin paljon" odotuksia raportoineet), \%. 
Taulukko 4. Palvelutietoa, sairautta ja sen hoitoa koskevien odotusfaktoreiden selittäviä tekijöitä: logistisen regressioanalyysin ristitulosuhteet (OR) ja luottamusvälit (lv) yksittäisissä analyyseissa (0-malli) ja kokonaismallissa (kovariantteina lapsen ikä ja kurssiryhmä).

\begin{tabular}{|l|c|c|c|c|c|c|c|c|}
\hline \multirow{2}{*}{ Selittäviä muuttujia } & \multicolumn{3}{|c}{ F1: Tietoa tukimuodoista ja palveluista } & \multicolumn{3}{c|}{ F5: Tietoa ja ohjausta sairauteen ja hoitoon } \\
\cline { 2 - 9 } & \multicolumn{2}{|c|}{ Yksittäin } & \multicolumn{2}{c|}{ Kokonaismalli } & \multicolumn{2}{c|}{ Yksittäin } & \multicolumn{2}{c|}{ Kokonaismalli } \\
\cline { 2 - 9 } & OR & $95 \%$ IV & OR & $95 \%$ Iv & OR & $95 \%$ Iv & OR & $95 \%$ Iv \\
\hline Lapsen ikä: korkeampi & $0.92^{*}$ & $0.87-0.98$ & $0.93^{*}$ & $0.88-1.00$ & $0.93^{*}$ & $0.87-0.98$ & $0.92^{* *}$ & $0.86-0.98$ \\
\hline Kurssiryhmä & & & & & & & & \\
\hline diabetes & 1 & & 1 & & 1 & & & \\
\hline opp ja psyyk keh häir & $2.71^{* *}$ & $1.54-4.78$ & $2.96^{* * *}$ & $1.66-5.27$ & 0.93 & $0.54-1.58$ & - & - \\
\hline moni- ja liikuntavamma & $4.19^{* * *}$ & $2.21-7.98$ & $3.89 * * *$ & $2.01-7.52$ & 0.91 & $0.50-1.64$ & - & - \\
\hline $\begin{array}{l}\text { Toimintakyvyn rajoitteen } \\
\text { haittaavuus: vähäisempi }\end{array}$ & $0.89^{*}$ & $0.81-0.99$ & 0.96 & $0.86-1.07$ & $0.90^{*}$ & $0.82-0.99$ & $0.88^{*}$ & $0.79-0.98$ \\
\hline $\begin{array}{l}\text { SDQ kp (4-17 v): } \\
\text { korkeammat oirepisteet }\end{array}$ & 1.03 & $0.98-1.07$ & - & - & 0.99 & $0.96-1.02$ & - & - \\
\hline $\begin{array}{l}\text { Vanhempien hyvinvointi: } \\
\text { parempi }\end{array}$ & $0.83^{*}$ & $0.69-0.99$ & 0.86 & $0.71-1.04$ & $0.79 *$ & $0.66-0.95$ & $0.79 *$ & $0.66-0.96$ \\
\hline $\begin{array}{l}\text { Perheiden valtaistuminen: } \\
\text { parempi }\end{array}$ & & & & & & & & \\
\hline sairauden tiedollinen hallinta & $0.64^{* *}$ & $0.47-0.88$ & $0.71^{*}$ & $0.51-0.98$ & $0.57^{* *}$ & $0.41-0.78$ & $0.56^{* *}$ & $0.40-0.78$ \\
\hline $\begin{array}{l}\text { itsearvostus ja valmius } \\
\text { sairaudesta puhumiseen }\end{array}$ & $0.65^{*}$ & $0.44-0.94$ & 0.74 & $0.50-1.11$ & $0.69 *$ & $0.48-0.99$ & 0.72 & $0.49-1.05$ \\
\hline $\begin{array}{l}\text { selviytymisen tunne ja } \\
\text { ongelmien hallinta }\end{array}$ & 0.88 & $0.65-1.19$ & - & - & $0.61^{* *}$ & $0.44-0.83$ & $0.55^{* * *}$ & $0.40-0.77$ \\
\hline
\end{tabular}

Tilastolliset merkitsevyydet: * $p<0.05 ; * * p<0.01 ; * * * p<0.001$.

Lapsen sukupuolella ja aikaisemmalla sopeutumisvalmennuksella ei ollut yhteyttä kurssiodotuksiin.

perheen selviytymisen ja ongelmien hallinnan osiot. (Taulukko 5.)

\section{Pohdinta}

Tutkimuksessa selvitettiin sopeutumisvalmennuskursseille osallistuneiden lasten vanhempien arvioita lapsen ja perheen hyvinvoinnista, kurssiodotuksiin liittyvistä tuen tarpeista ja niihin yhteydessä olevista tekijöistä. Tutkimuksen kohteena olivat Kelan järjestämät diabetes-, oppimisen- ja psyykkisen kehityksen häiriöiden sekä moni- ja liikuntavammaisten kurssit, joille lapset osallistuivat yleensä yhdessä perheenjäsenten kanssa. Aineistossa pojat olivat yliedustettuina kaikissa ryhmissä, mutta erityisesti oppimisen ja psyykkisen kehityksen häiriöiden kursseilla. Pojilla esiintyykin tyttöjä useammin erilaisia kehityksellisiä häiriöitä ja erityispalveluiden tarvetta (esim. Gyllenberg ym. 2014).

Valtaosa vanhemmista arvioi lapsensa terveydentilan hyväksi, vaikka erilaisia toimin- nallisia rajoituksia lapsilla arvioitiin esiintyvän melko paljon. Kurssiryhmät eivät eronneet toisistaan terveydentilan suhteen eikä terveydentilan arviolla myöskään ollut vahvaa yhteyttä lapsen toimintarajoitteiden määrään tai haittaavuuden asteeseen. Myös aikaisemmissa tutkimuksissa vammaisten lasten terveydentila on arvioitu kohtalaisen hyväksi silloinkin, kun vamman haittaavuus on ollut varsin suuri tai siihen on liittynyt erilaisia rajoitteita (Notko ym. 2009, Almasri ym. 2011, 2014). Tässä tutkimuksessa lapsen toimintakyky ja hyvinvointi arvioitiin diabetesta sairastavilla lapsilla paremmiksi kuin lapsilla, joilla oli ns. kehityksellinen häiriö. Myös Varnin ym:iden (2007) tutkimuksessa diabetesta sairastavien lasten omat ja vanhempien arviot lasten elämänlaadusta olivat myönteisemmät kuin lapsilla, joilla oli kehityksellisiä ongelmia. Toisaalta useat tutkimukset osoittavat, että lapsen elämänlaatu voi olla hyvä vammojen ja sairauksien aiheuttamista haitoista huolimatta (Dickinson ym. 2007, Notko ym. 2009, Böling ym. 2016). 


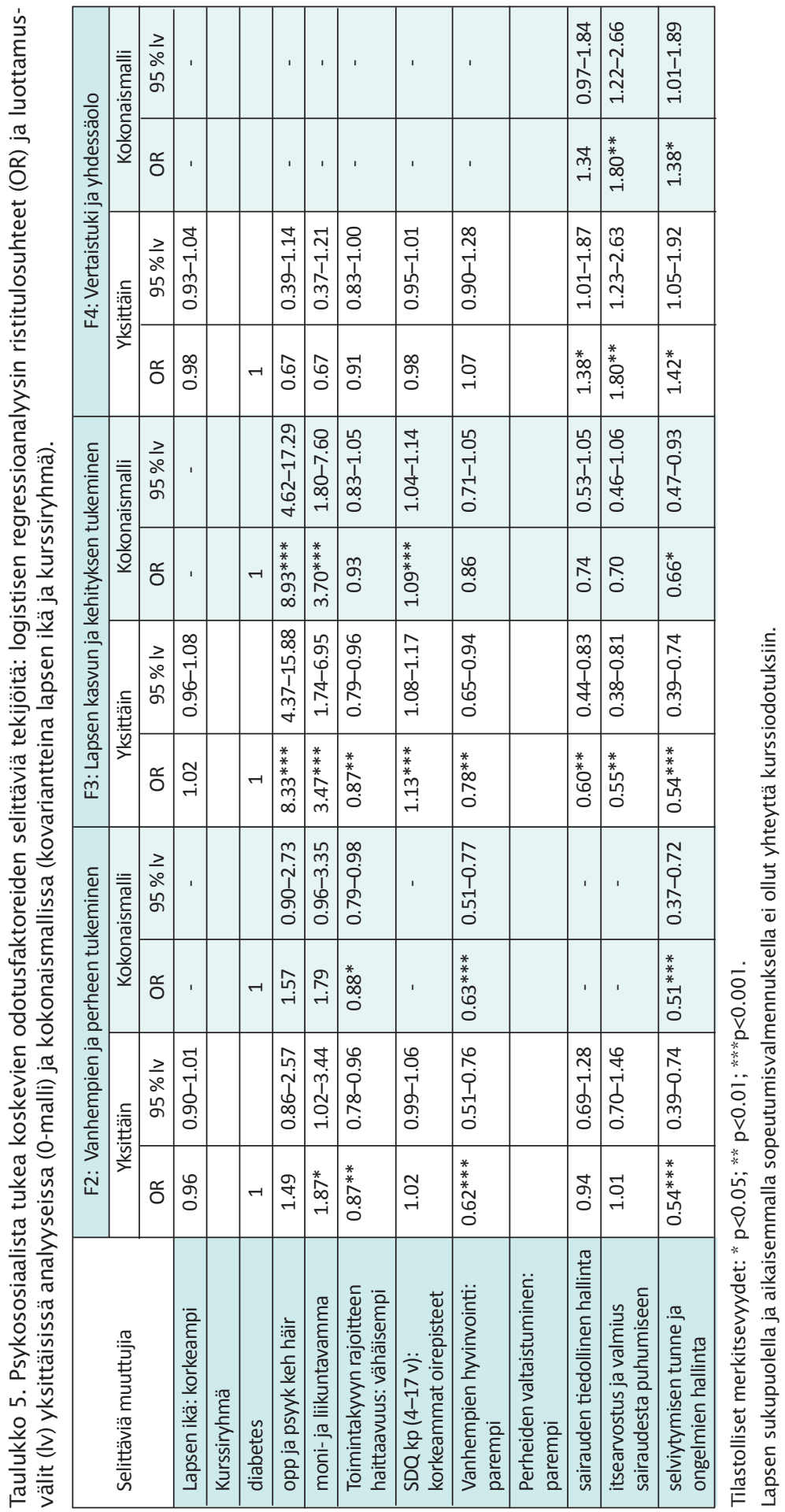


Kaikissa kurssiryhmissä vanhemmat arvioivat oman ja perheen hyvinvoinnin kohtalaisen hyväksi, diabetesryhmässä arviot olivat kuitenkin muita ryhmiä myönteisemmät. Vanhempien hyvinvointiin vaikuttavat lapsen käyttäytymisen ohella muun muassa palvelujen perhekeskeisyys, sosiaalinen tuki sekä erilaiset sosioekologiset ja taloudelliset tekijät (esim. King ym. 1999, Sloper \& Beresford 2006). Tässä tutkimuksessa vanhempien arvio omasta hyvinvoinnistaan korreloi melko vahvasti sekä lapsen että sisarusten hyvinvointia koskeviin arvioihin. Tulokset tukevat aikaisempia tutkimustuloksia, joiden mukaan lapsen sairauden tai vammaisuuden perusteella toteutettavia interventioita kehitettäessä tulisi kiinnittää huomiota koko perheen hyvinvointiin ja selviytymiskeinoihin (Compas ym. 2012, Giallo ym. 2014, Morawska ym. 2015).

Perhekeskeisten palveluiden ydinajatuksena on, että perhe on lapsen paras asiantuntija, lasta autetaan parhaiten auttamalla koko perhettä ja palveluiden tulisi vastata perheiden tarpeisiin (Perrin ym. 2007, Dempsey \&t Keen 2008). Tarveperustaisia ja perhekeskeisiä käytäntöjä on pidetty ns. parhaina käytäntöinä lasten kuntoutuksessa (Almasri ym. 2011). Vanhempien ja lasten tarpeiden ja toiveiden huomioonotto kuntoutuksen suunnittelussa ja toteutuksessa on yhteydessä perheiden tyytyväisyyteen ja parempiin koettuihin kuntoutustuloksiin (Järvikoski ym. 2013, 2015). Tässä tutkimuksessa vanhemmilla oli monenlaisia odotuksia sopeutumisvalmennuskurssin sisällöistä ja hyödyistä. Eniten odotuksia kohdistui toisaalta sopeutumisvalmennuskursseilta saatavaan vertaistukeen, yhdessäoloon ja virkistäytymiseen, toisaalta lapsen sairautta koskevaan tietoon ja tukeen.

Vertaistukeen liittyvät odotukset ja tuen merkityksellisyys erityistä tukea tarvitsevien lasten perheille on tunnistettu myös aikaisemmissa suomalaisissa tutkimuksissa (esim. Linnakangas ym. 2010, Autti-Rämö ym. 2015). Vanhemmat voivat vertaistuen kautta jakaa sosiaalista identiteettiä, oppia toisten kokemuksista ja kokea henkilökohtaista kasvua ja valtaistumista. He saavat myös mahdollisuuden tukea toisia, mikä voi lisätä itsearvostuk- sen tunnetta. (Esim. Shilling ym. 2013.) Vertaistuki voi olla sekä tiedollista että emotionaalista, ja se voi vahvistaa osallistujien selviytymiskeinoja ja hyvinvointia (esim. Pfeiffer ym. 2011, Embuldeniya ym. 2013). Tämän tutkimuksen vanhemmat odottivat kurssilta myös virkistäytymistä ja mukavaa yhdessäoloa. Tämä on ymmärrettävää, sillä lapsen pitkäaikaissairaus aiheuttaa usein perheille lisäkuormitusta. Hengähdystaukoa hoidosta ja vanhempien omaa aikaa pidettiin tärkeänä esimerkiksi perheissä, joissa lapsilla esiintyi autismikirjon häiriöitä (Hodgetts ym. 2015).

Vanhemmat tarvitsivat myös tietoa sairauden hoidosta ja kuntoutuksesta - myös silloin, kun perhe oli jo aikaisemmin osallistunut sopeutumisvalmennuskurssille. Erityistä tukea tarvitsevien lasten vanhempien tarpeeseen saada tietoa toimintakykyyn vaikuttavista tekijöistä, hoidosta ja palveluista on kiinnitetty huomiota perhekeskeisiä kuntoutuskäytäntöjä selvittävissä tutkimuksissa (esim. Jeglinsky ym. 2012, Alsem ym. 2014, Hodgetts ym. 2015). Tässä tutkimuksessa palveluja koskevat tiedon tarpeet olivat vähäisemmät diabetesta sairastavien lasten vanhemmilla kuin ns. kehityksellisten häiriöiden kurssiryhmissä. Vuorenmaa (2016) on todennut, että mitä paremmaksi vanhemmat arvioivat tiedonsaantinsa palveluista, sitä vahvemmaksi he arvioivat oman osallisuutensa tai valtaistumisensa niin perheessään kuin palveluissa.

Tutkimuksessa selvitettiin, millaiset tekijät olivat yhteydessä kurssiodotuksiin. Pienten lasten vanhemmat odottivat palveluihin ja sairauden hoitoon ja kuntoutukseen liittyvää tietoa ja tukea enemmän kuin vanhempien lasten vanhemmat. Myös lapsen hyvinvoinnin tai toimintakyvyn ongelmat lisäsivät laaja-alaiseen ammatilliseen tukeen ja tietoon liittyviä odotuksia ja tarpeita. Tutkimuksen keskeinen tulos koski perheen valtaistumisen ja kurssiin kohdistuneiden odotusten välisiä yhteyksiä. Tarvetta ammatilliseen asiantuntijuuteen perustuvaan tietoon, psykososiaaliseen tukeen ja ohjaukseen ilmaisivat erityisen voimakkaasti ne perheet, joilla tilanteen tiedollinen hallinta ja valtaistumisen tunne olivat keskimääräistä heikommat. Sen sijaan 
ne vanhemmat, joilla oman tilanteen tuntemus ja tiedollinen hallinta oli keskimääräistä parempi, odottivat kurssilta muita useammin vertaistukea, virkistäytymistä ja yhdessäoloa. Perheiden valtaistuminen, vanhempien aktiivinen osallisuus palveluissa ja heidän valmiutensa selviytyä arjen haasteista lapsen kanssa ovat tärkeitä tavoitteita palveluiden kehittämistyössä (Koren ym. 1992, Vuorenmaa 2016). Vähemmän on kuitenkin kiinnitetty huomiota siihen, että valtaistumisensa suhteen eri tilanteissa olevat perheet tarvitsevat ja pystyvät käyttämään hyödykseen erilaista tukea. Mielenkiintoista on myös, että aikaisemmissa tutkimuksissa on kiinnitetty huomiota vertaistuen mahdollisuuteen tukea ja vahvistaa valtaistumista (Banach ym. 2010, Embuldeniya ym. 2013, Shilling ym. 2013, Vuorenmaa 2016). Tämän tutkimuksen mukaan vahvemmin valtaistuneet perheet odottivat kursseilta erityisesti vertaistukea, kun taas vähemmän valtaistuneiden perheiden tarpeet ja odotukset liittyvät enemmän ammatillisen tuen saamiseen. Valtaistumisen, vertaistuen ja ammatillisen tuen vaikutusyhteyksiä olisikin tärkeä selvittää tarkemmin jatkotutkimuksissa.

Tutkimuksen rajoitukset on otettava huomioon tuloksia tarkasteltaessa. Vastausprosentti (59 \%) jäi vain kohtalaiseksi ja vaihteli kurssikohtaisesti; matalin (50\%) se oli monija liikuntavammaisten lasten kursseilla. Vastaamattomuuden taustalla on todennäköisesti erilaisia syitä. Ne voivat liittyä perheiden tilanteeseen, tiedonkeruun tapaan tai palveluntuottajien toimintaan. Lomakkeeseen vastaajina olivat useimmiten äidit, kuten useissa muissakin erityistä tukea tarvitsevien lasten tarpeita selvittävissä tutkimuksissa (esim. Almasri 2011, Alsem 2014). Tulokset voisivat olla osittain erilaisia, jos isät olisivat olleet useammin mukana vastaajina. On kuitenkin tutkimuksia, joiden mukaan äitien ja isien arvioissa omasta hyvinvoinnistaan (esim. Ha ym. 2008) tai saadusta tuesta (Jansen ym. 2012) ei ole merkittäviä eroja. Tutkitut kurssiryhmät erosivat toisistaan iän suhteen, ja pienten lasten tuen tarpeet voivat olla erilaisia kuin vanhempien lasten. Iän kontrollointi ei kuitenkaan muuttanut oleellisesti ryhmien välisiä eroja.
Kurssiryhmien välillä oli myös muita eroja, joiden vaikutuksia arvioihin ei voitu kontrolloida. Kurssiryhmien odotuksia verrattaessa on myös huomattava, että Kelan kurssikohtaiset standardit (Kela 2013) painottavat osittain erilaisia asioita eri kohderyhmien sopeutumisvalmennuksen toteutuksessa.

Rajoituksista huolimatta tutkimuksen perusteella voidaan todeta, että erityistä tukea tarvitsevien lasten vanhemmilla on sopeutumisvalmennukseen tullessaan monenlaisia odotuksia, yleisimpinä vertaistuki, virkistäytyminen sekä sairautta ja palveluja koskevan informaation saanti. Vanhempien arviot omasta ja lapsen hyvinvoinnista, lapsen toimintakyvyn rajoitteiden luonne ja perheiden terveyteen liittyvä valtaistuminen vaikuttavat siihen, millaista tukea kurssilta odotetaan saatavan. Perheet, joilla valtaistuminen on heikompaa, odottavat saavansa kursseilta muita useammin ammatillista psykososiaalista tukea ja tietoa. Vahva valtaistumisen tunne liittyy suurempiin odotuksiin vertaistuesta ja vähäisempiin odotuksiin asiantuntijatiedosta tai -tuesta. Sopeutumisvalmennuksen toteutuksessa on tärkeä ottaa huomioon perheiden erilaiset tarpeet sekä tunnistaa niiden taustalla olevia yksilöllisiä ja sosiaalisia tekijöitä.

\section{Tiivistelmä}

Sopeutumisvalmennus on psykososiaalista kuntoutusta, joka tarjoaa tietoa ja tukea sairaudesta tai vammasta, sen hoidosta ja selviytymiskeinoista. Lapset ja nuoret, joilla on pitkäaikaissairaus tai kehityksen häiriöitä, osallistuvat sopeutumisvalmennukseen useimmiten perheenjäsentensä kanssa. Tämän tutkimuksen tavoitteena oli 1) selvittää vanhempien käsityksiä lasten hyvinvoinnista ja toimintakyvystä, 2) arvioida vanhempien omaa hyvinvointia ja perheiden valtaistumista ja 3) selvittää kurssiodotuksia ja niihin yhteydessä olevia tekijöitä. Tutkimus kohdistui Kelan kuntoutuksena vuosina 2014-15 toteutettuihin diabeteskursseihin, oppimisen tai psyykkisen kehityksen häiriöiden kurssei- 
hin sekä moni- ja liikuntavammaisten lasten kursseihin. Lasten vanhemmat vastasivat kurssin alussa lomakekyselyyn ( $\mathrm{n}=$ 357, vastausprosentti $59 \%$ ).

Kaikissa kurssiryhmissä useimmat vanhemmat arvioivat lapsen terveydentilan hyväksi tai melko hyväksi. Vanhempien arviot niin omasta kuin lapsenkin hyvinvoinnista erosivat kurssiryhmittäin, mutta myös kurssiryhmien sisällä ilmeni vaihtelua. Vanhemmat, joiden lapsella oli diabetes, arvioivat hyvinvointia myönteisemmin kuin vanhemmat, joiden lapsella oli kehityksellinen häiriö. Vanhempien arviot omasta hyvinvoinnistaan korreloivat melko vahvasti lasta koskeviin hyvinvointiarvioihin. Sopeutumisvalmennukseen liittyvät odotukset ja tuen tarpeet koskivat erityisesti vertaistukea ja virkistäytymistä sekä tiedon saantia sairaudesta ja sen hoidosta ja kuntoutuksesta. Kurssiryhmä, lapsen toimintakyvyn rajoitteet, vanhempien hyvinvointi ja perheiden valtaistuminen olivat yhteydessä perheiden odotuksiin ja tuen tarpeisiin. Tutkimuksen keskeinen tulos koski perheen valtaistumisen ja kurssiodotusten välistä yhteyttä. Tarve ammatilliseen asiantuntijuuteen pohjautuvaan tietoon ja psykososiaaliseen tukeen oli vahvempaa niillä perheillä, joilla valtaistumisen tunne oli heikompaa. Sen sijaan ne perheet, joilla valtaistuminen oli voimakkaampaa, odottivat kursseilta vähemmän asiantuntijan tukea ja enemmän vertaistukea ja virkistäytymistä.

\section{Abstract}

Parents' evaluations of their children's wellbeing and functioning and identified expectations for psychosocial rehabilitation

Authors:

Anu Kippola-Pääkkönen, M.Soc.Sc., researcher, University of Lapland

Kristiina Härkäpää, PhD, professor, Uni- versity of Lapland

Aila Järvikoski, D.Soc.Sc., professor emerita, University of Lapland

Ilona Autti-Rämö, $M D$, medical director, research professor, The Social Insurance Institution of Finland

Finnish adaptation training represents psychosocial rehabilitation, which aims to offer information and guidance for living with an illness or disability as well as promoting coping skills. Children and adolescents with chronic illnesses or developmental disorders participate adaptation training mostly with their family members. The aim of this study was to 1) examine the parents' perceptions of their child's wellbeing and functioning, 2) depict their assessments on their own wellbeing and family empowerment, and 3) investigate their needs and expectations for the adaptation training as well as factors connected with different expectations. The study focused on three courses arranged for children either with diabetes, learning or psychological development disorders or multiple or mobility disabilities. The courses were organized in three rehabilitation centers. The parents answered the questionnaire at the beginning of the course ( $n=357$, response rate $59 \%$ ).

In all course groups most parents perceived their child's health fairly good or good. The parents of children with diabetes evaluated their child's wellbeing more positively than the parents of children with developmental disorders. The parents' wellbeing correlated positively with the children's wellbeing. Strongest rehabilitation needs and expectations were related to the domains of peer support and recreation, and information about illness or disability and its treatment. The course group, disability of the child, wellbeing of parents and children, and family empowerment were associated with the expectations and needs factors. The main finding of this study addressed the relationship of 
the family empowerment to the expectation domains. Families with weaker empowerment expressed more expectations and needs for professional information and support. More strongly empowered families expressed less needs for professional support and information but more expectations for peer support and recreation.

\section{Anu Kippola-Pääkkönen, YTM, tutkija, Lapin yliopisto}

Kristiina Härkäpää, FT, professori, Lapin yliopisto

Aila Järvikoski, YTT, professori (emerita), Lapin yliopisto

Ilona Autti-Rämö, LT, johtava ylilääkäri, tutkimusprofessori, Kansaneläkelaitos

\section{Lähteet}

Ahlgren T, Poikkeus L (2014) Terveydenhuolto, Kela ja RAY sopeutumisvalmennuksen mahdollistajana: Kela. Teoksessa H Streng (toim.) Sopeutumisvalmennus: suomalaisen kuntoutuksen oivallus. Raha-automaattiyhdistys, Espoo.

Almasri NA, O'Neil M, Palisano RJ (2014) Predictors of needs for families of children with cerebral palsy. Disabil Rehabil 36, 3, 210-219.

Almasri NA, Palisano RJ, Dunst CJ, Chiarello LA, 0'Neil ME, Polansky M (2011) Determinants of needs of families of children and youth with cerebral palsy. Child Health Care, 40, 130-154.

Alsem MW, Siebes RC, Gorter JW, Jongmans MJ, Niijhuis BGJ, Ketelaar M (2014) Assesment of family needs in children with physical disabilities: development of a family needs inventory. Child Care Health Dev, 40,1, 498-506.

Autti-Rämö I, Kippola-Pääkkönen A, Valkonen J, Tuulio-Henriksson A, Härkäpää K (2015) Narkolepsiaan sairastuneiden lasten ja nuorten perheiden arki ja sopeutumisvalmennuskurssilta saatu tuki. Sosiaali- ja terveysturvan selosteita 90. Kela, Helsinki.

Banach M, Iudice J, Conway L, Couse LI (2010) Family support and empowerment: post autism diagnosis support group for parents. Soc Work Groups 33, 1, 69-83.

Benson PR, Kersh J (2011) Marital quality and psychological adjustment among mothers of children with ASD: cross-sectional and longitudinal relationships. J Autism Dev Disord, 41, 1675-1685.

Borg AM, Kaukonen P, Salmelin R, Joukamaa M, Tamminen T (2012) Reliability of the strengths and difficulties questionnaire among Finnish 4-9-yearold children. Nord J Psychiatry, 66, 6, 403-413.

Burton P, Lethbridge L and Phipps S (2008) Children with disabilities and chronic conditions and longer-term parental health. J Socio Econ 37, 3, 11681186.

Böling S, Varho T, Kiviranta T, Haataja L (2016) Quality of life of Finnish children with cerebral palsy. Disabil Rehabil, 38,7, 683-688.

Compas BE, Jaser SS., Dunn MJ, Rodrigueaz EM (2012) Coping with chronic illness in childhood and adolescence. Annu Rev Clin Psychol, 8, 455-480.

Cousino MK \&t Hazen RA (2013) Parenting stress among caregivers of children with chronic illness: a systematic review. J Pediatric Psychol, 38, 8, 809-828.

Dagnan D (2007) Psychosocial interventions for people with intellectual disabilities and mental ill-health. Curr Opin Psychiatry 20, 5, 456-460.

Dempsey I, Keen D (2008) A review of processes and outcomes in family-centered services for children with a disability. Topics Early Child Spec Educ, 28, 1, 42-52.

Dickinson HO, Parkinson KN, Ravens-Sieber U, Schirripa G, Thyen U, Arnaud C et al. (2007) Self-reported quality of life of 8-12 - year-old children with cerebral palsy: a cross-sectional European study. Lancet, 369, 2171-2178.

Embuldeniya G, Veinot P, Bell E, Bell M, Nyhof-Young J, Sale JEM and Britten N (2013) The experience and impact of chronic disease peer support interventions: A qualitative synthesis. Patient Educ Couns 92, 1, 3-12.

Giallo R, Roberts R, Emerson E, Wood C, GavidiniaPayne S (2014) The emotional and behavioural functioning of siblings of children with special health care needs across childhood. Res Dev Disabil, 35, 4, 814-825.

Giovagnoli G, Postorino V, Fatta LM, Sanges V, De Pappo L, Vassena L, De Rose P, Vicari S, Mazzone L (2015) Behavioral and emotional profile and parental stress in preschool children with autism spectrum disorder. Res Dev Disabil, 45-46, 411-421.

Goodman R (1997) The Strengths and Difficulties Questionnaire: A Research Note. J Child Psychol Psychiatry, 38, 581-586.

Goodman R (2001) Psychometric properties of the strengths and difficulties questionnaire. J Am Acad 
Child Adolesc Psychiatry, 40, 11, 1337-1345.

Grey M, Jaser SS, Whittemore R, Jeon S, Lindemann E (2011) Coping skills training for parents of children with type 1 diabetes: 12-month outcomes. Nurs res, 60, 3, 173-181. Saatavissa: < doi: 10.1097/ NNR.0b013e3182159c8f >. Viitattu 13.1.2016.

Gyllenberg D, Gissler M, Malm H, Artama M, HinkkaYli-Salomäki S, Brown AS, Sourander A (2014) Specialized service use for psychiatric and neurodevelopmental disorders by age 14 in Finland. Psych Serv 65, 3, 367-373.

Ha JH, Hong J, Seltzer MM, Greenberg JS (2008) Age and gender differences in the well-being of midlife and aging parents with children with mental health or developmental problems: Report of a national study. J Health Social Behav, 49, 3, 301-316.

Hodgetts S, Zwaigebaum L, Nicholas D (2015) Profile and predictors of service needs for families of children with autism spectrum disorders. Autism, 19, 6, 673-683.

Homan-Helenius P (2005) Empowering families of children with asthma through adaptation training. Turun yliopiston julkaisuja. Annales Universitatis Turkuensis Sarja D, osa 669. Akateeminen väitöskirja. Turun yliopisto, Turku.

Houtrow AJ, Okumura MJ, Hilton JF, Rehm RS (2011) Profiling health and health-related services for children with special health care needs with and without disabilities. Acad Pediatr, 11, 508-516.

Jansen SLG, van der Putten AAJ, Vlaskamp C (2012) What parents find important in the support of a child with profound intellectual and multiple disabilities. Child Care Health Dev 39, 3, 432-41.

Jeglinsky I, Autti-Rämö I, Brogren Carlberg E (2012) Two sides of the mirror: parents's and service providers'view on the family-centredness of the care for the children with cerebral palsy. Child Care Health Dev, 38, 1, 79-86.

Järvikoski A, Härkäpää K (2014) Teoreettisia näkökulmia psykososiaaliseen sopeutumiseen ja sopeutumisvalmennukseen. Teoksessa H Streng (toim.) Sopeutumisvalmennus: suomalaisen kuntoutuksen oivallus. Raha-automaattiyhdistys, Espoo.

Järvikoski A, Härkäpää K, Martin M, Vasari P (2015) Service characteristics as predictors of parents'perceptions of child rehabilitation outcomes. J Child Health Care, 19, 1, 106-117.

Järvikoski A, Martin M, Autti-Rämö I, Härkäpää K (2013) Shared agency and collaboration between the family and professionals in medical rehabilitation of children with severe disabilities. Int $\mathrm{J}$ Rehabil Res, 36, 30-37.

Kela (2013) Kuntoutuksen standardit. Saatavissa: < http://www.kela.fi/standardit_hyvaksytyt-standardit >. Viitattu 13.1.2016.

King G, King S, Rosenbaum P, Goffin R (1999) Family-centered caregiving and well-being of parents of children with disabilities: linking process with outcome. J Pediatr Psychol, 24,1, 41-53.

Koskelainen M, Sourander A, Kaljonen A (2000) The Strengths and Difficulties Questionnaire among Finnish school-aged children and adolescents. Eur Child Adolesc Psychiatry, 9, 4, 277-284.

Koskelainen M, Sourander A, Vauras M (2001) Selfreported strengths and difficulties in a community sample of Finnish adolescents. Eur Child Adolesc Psychiatry, 10, 3, 180-185.

Koren PE, DeChillo N, Friesen BJ (1992) Measuring empowerment in families whose children have emotional disabilities: A brief questionnaire. Rehabil Psychol, 37,4, 305321.

Law EF, Fisher E, Fales J, Noel M, Eccleston C (2014) Systematic review and meta-analysis of parent and family-based interventions for children and adolescents with chronic medical conditions. J Pediatr Psychol, 39, 8, 866-886.

Linnakangas R, Lehtoranta P, Järvikoski A, Suikkanen A (2010) Perhekuntoutus puntarissa. Kelan psykiatrisen perhekuntoutuksen kehittämishankkeen arviointi. Sosiaali- ja terveysturvan tutkimuksia 109. Kela, Helsinki.

Miodrag N, Burke M, Tanner-Smith E, Hodapp RM (2015) Adverse health in parents of children with disabilities and chronic health conditions: a metaanalysis using the parenting stress index's health sub-domain. J Intellectual Disabil Res, 59, 3, 257271.

Montoya A, Colom F, Ferrin M (2011) Is psychoeducation for parents and teachers of children and adolescents with ADHD efficacious? A systematic literature review. Eur Psychiatry, 26, 166-175.

Morawska A, Calam R, Fraser J (2015) Parenting interventions for childhood chronic illness: A review and recommendations for intervention design and delivery. J Child Health Care, 19, 1, 5-17.

Mäenpää H (2014) Terveydenhuolto, Kela ja RAY sopeutumisvalmennuksen mahdollistajana: Terveydenhuollon näkökulma. Teoksessa H Streng (toim.) Sopeutumisvalmennus: suomalaisen kuntoutuksen oivallus. Raha-automaattiyhdistys, Espoo.

Nachshen JS, Minnes P (2005) Empowerment in parents of school-aged children with and without developmental disabilities. J Intellectual Disabil Res, 49, 12, 889-904.

Notko T, Martin M, Puumalainen J (2009) Kelan kuntoutukseen osallistuneiden lasten elämäntilanne. 
Teoksessa A Järvikoski, L Hokkanen, K Härkäpää (toim.) Asiakkaan äänellä. Odotuksia ja arvioita vaikeavammaisten lääkinnällisestä kuntoutuksesta. Kuntoutussäätiön tutkimuksia 80, Kuntoutussäätiö, Helsinki.

Nylén M, Tervonen S, Leino E (2009) Hoidonohjauksen ja kuntoutuksen merkitys epilepsiapotilaan kannalta. Duodecim, 125, 2543-2551.

Pfeiffer PN, Heisler M, Piette JD, Rogers MA and Valenstein M (2011) Efficacy of peer support interventions for depression: a meta-analysis. Gen Hosp Psychiatry 33, 1, 29-36.

Perrin JM, Romm D, Bloom SR, Homer CJ, Kuhlthau KA, Cooley C., ym. (2007) A family-centered, community-based system of services for children and youth with special health care needs. Arch Pediatr Adolesc Med, 161, 10, 933-936.

Rantala A (2002) Perhekeskeisyys -puhetta vai todellisuutta? Työntekijöiden käsitykset yhteistyöstä erityistä tukea tarvitsevan lapsen perheen kanssa. Jyväskylä studies in education, psychology and social research 198. Akateeminen väitöskirja. Jyväskylän yliopisto, Jyväskylä.

Ruutiainen J (2003) Kuntoutus kannattaa MS-taudissa. Suomen Lääkärilehti, 58, 5055-5058.

SDQ. Information for researchers and professionals about the Strengths \& Difficulties Questionnaires

Saatavissa: $<$ http://www.sdqinfo.com >. Viitattu 13.1.2016.

Shilling V, Morris C, Thompson-Coon J, Ukoumunne 0, Rogers M and Logan S (2013) Peer support for parents of children with chronic disabling conditions: a systematic review of quantitative and qualitative studies. Dev Med Child Neurol 55, 7, 602-609.

Sloper T, Beresford B (2006) Families with disabled children. BMJ 4, 333, 7575, 928-929.

Tengland PA (2008) Empowerment: A Conceptual Discussion, Health Care Anal, 16, 2, 77-96.

Theule J, Wieners J, Tannock R, Jenkins JM (2012) Parenting stress in families of children with $\mathrm{ADHD}$ : A meta-analysis. J Emot Beh Disord, 21, 1, 3-17.

Varni JW, Limbers CA, Burwinkle TM (2007) Impaired health-related quality of life in children and adolescents with chronic conditions: a comparative analysis of 10 disease clusters and 33 disease categories/severities utilizing the PedsQLTM 4.0 Generic Core Scales. Health Qual Life Outcomes, 5,43. Saatavissa: < doi: 10.1186/1477-7525-5-43 $>$. Viitattu 24.1.2016.

Vuorenmaa M (2016) Äitien ja isien osallisuus perheessä ja lasten palveluissa sekä osallisuuteen yhteydessä olevat tekijät. Acta Universitatis Tampe- rensis 2134. Akateeminen väitöskirja. Tampereen yliopisto, Tampere.

Zwi M, Jones H, Thorgaard C, York A, Dennis JA (2011) Parent training interventions for Attention Deficit Hyperactivity Disorder (ADHD) in children aged 5 to 18 years. Cochrane Database Syst Rev, 7,12, CD003018. 